\title{
МОДИФІКОВАНІ ФАКТОРИ РИЗИКУ ІШЕМІЧНОЇ ХВОРОБИ СЕРЦЯ У СВІТІ
}

\author{
О. Л. Сидоренко, Н. М. Ковбаса, В. Є. Деусь \\ КЗ ТОР “Тернопільська університетська лікарня» \\ ДвНЗ «Тернопільський державний медичний університет \\ імені I. Я. Горбачевського МОЗ України»
}

\begin{abstract}
У статті проведено порівняльну характеристику факторів ризику розвитку ішемічної хвороби серця серед населення різних регіонів світу, зокрема Європи, України, США та Субсахаральної Африки. Наголошено на важливості усунення модифікованих факторів ризику як засобу зниження серцево-судинної смертності у світі.
\end{abstract}

\section{MODIFIABLE RISK FACTORS FOR ISCHEMIC HEART DISEASE IN THE WORLD}

\author{
O. L. Sydorenko, N. M. Kovbasa, V. Ye. Deus \\ ME of TRC «Ternopil University Hospital» \\ I. Horbachevsky Ternopil State Medical University
}

The article presents a comparative description of risk factors for coronary heart disease among people of different regions of the world, including Europe, Ukraine, US and Sub-Saharan Africa. The importance of the elimination of modified risk factors as a means of reducing cardiovascular mortality in the world.

Вступ. Серцево-судинні захворювання (ССЗ) $є$ надзвичайно актуальною проблемою охорони здоров'я індустріально розвинутих країн світу незважаючи на постійне вдосконалення засобів діагностики та лікування кардіологічних хворих [18] - щорічно від СС3 помирає близько 17,5 мільйона людей [10]. Причому, за прогнозами експертів ВООЗ, до 2020 року ця патологія посяде перше місце і у структурі смертності країн, що розвиваються [18].

Основна частина. На сьогодні ССЗ є основною причиною смертності населення і більшості розвинених країн Європи, зумовлюючи майже $40 \%$ усіх випадків смерті [2]. Аналогічна проблема спостерігається івУкраїні, де впродовж останніх 10 років поширеність ССЗ серед дорослого населення зросла на 8,4 \%, а частка у загальній структурі смертності $\epsilon$ стабільно високою та становить на даний час 66,6 \% [3]. Смертність від ССЗ унашій країні, на жаль, залишається набагато вищою, ніж у Європі. Так, у Польщі вона нижча в 2,3 раза, у Швеції - майже в 4 рази, у Великій Британії - в 4,6 раза, у Франції - у 6 разів [11].

Захворюваність на серцево-судинну патологію $\epsilon$ нижчою у країнах із недостатнім рівнем доходів по-

(ㄷ О. Л. Сидоренко, Н. М. Ковбаса, В. Є. Деусь, 2016 рівняно з іншими регіонами світу. Зокрема, в Субсахаральній Африці ССЗ були причиною зареєстрованих смертей лише у 10 \% випадків [20]. У період від 1997 до 2004 рр. на цій території помирало 70 тис. осіб щороку від цієї патології, причому в структурі причин смертності білошкірих африканців переважав гострий інфаркт міокарда, а чорношкірих - інсульт, некоронарогенні захворювання міокарда та артеріальна гіпертензія (АГ) [19].

На сучасному етапі в світі спостерігається тенденція до зростання поширеності найбільш соціально значущих ССЗ, зокрема ішемічної хвороби серця (IXC). Її важливість зумовлена значною поширеністю, високою смертністю, інвалідизацією та великими соціально-економічними витратами, які впливають на трудовий потенціал населення. На сьогодні саме ця патологія на 66,8 \% визначає рівень смертності від СС3 усього населення і на 54,4 \% - його працездатної частини [2]. Щорічно в світі від IXC помирають 7,4 мільйона осіб [10].

IXC $\epsilon$ також найчастішою причиною втрати працездатності та смертності і у Європі, зумовлюючи близько 2 мільйони смертей їі жителів щорічно [8]. Поширеність даної нозології в Україні серед осіб працездатного віку 
в 2011 році становила 9,6 тис. на 100 тис. населення

[7]. Аналізуючи дані, наведені у Європейській базі
«Здоров'я для всіх», Україна, на жаль, лідирує за показниками смертності від IXC у даному регіоні (рис. 1) [1].

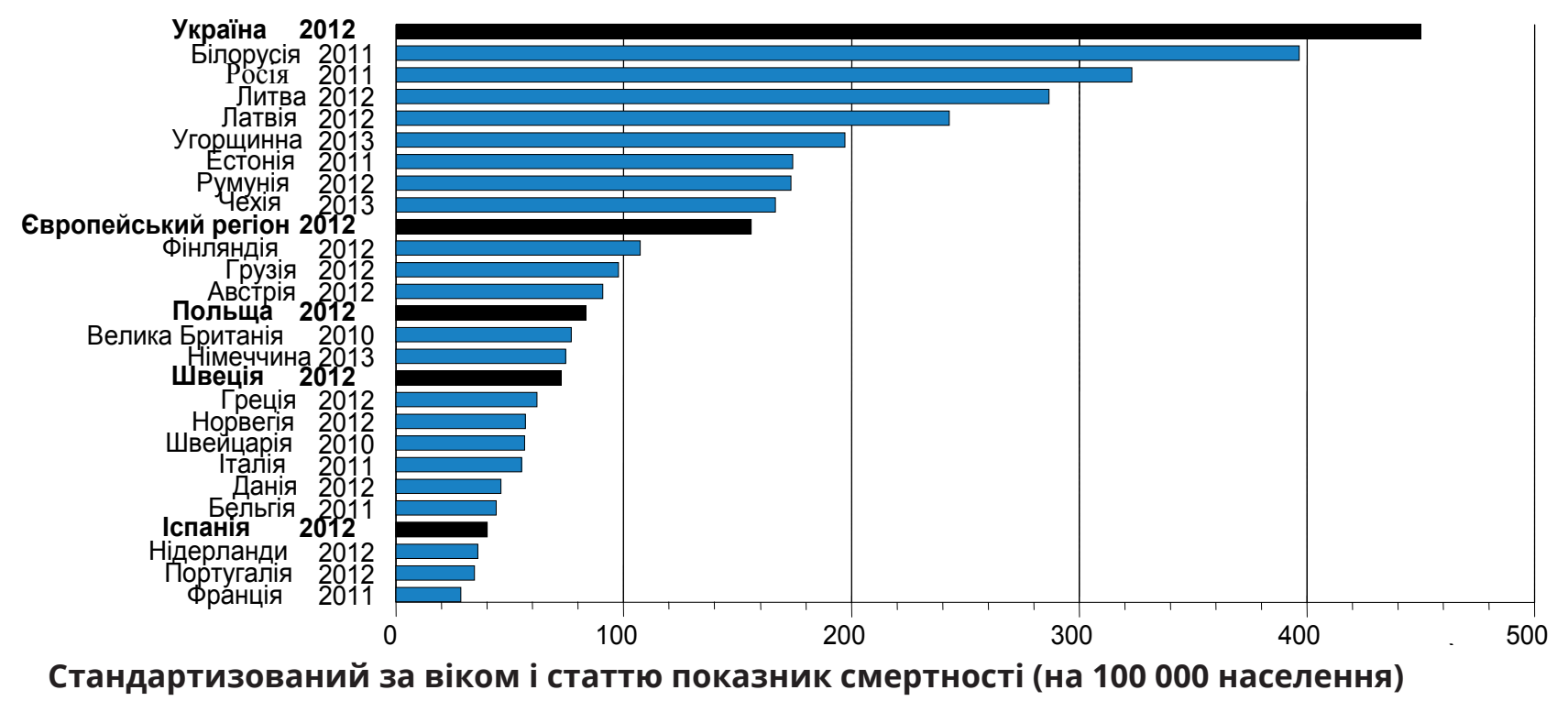

Puc. 1. Смертність від IXC за Європейською базою даних статистичної інформації «Здоров'я для всіх» [1].

Подібна тенденція щодо збільшення частки IXC у структурі захворюваності та смертності спостерігається і у всіх інших країнах світу. У США, за результатами епідеміологічного дослідження дорослого населення, більше 13 мільйонів людей страждають від даної патології. Фінансове навантаження, що пов'язане з IXC у цій країні досягає 150 мільярдів доларів щороку [15].

Також, урбанізація, швидкі темпи економічного розвитку, подовження тривалості життя серед населення в країнах Африки південніше Сахари зумовлює зростання поширеності АГ, цукрового діабету, ожиріння та дисліпідемії. Внаслідок збільшення частки вказаних модифікованих факторів ризику розвитку атеросклерозу очікується, що смертність від IXC на цій території зросте на 27 \% для чоловіків і 25 \% для жінок до 2015 року і на 70 і 74 \%, відповідно, до 2030 року [21, 17].

В умовах сучасних соціально-економічних ситуацій різних регіонів світу головним напрямком охорони здоров'я на сьогодні стає власне первинна профілактика СС3, зокрема усунення факторів ризику IXC, що пов'язані зі стилем життя - тютюнокуріння, гіподинамія, нераціональне харчування, ожиріння та інші, які часто поєднуються із АГ, цукровим діабетом (ЦД) 2-го типу та дисліпідемією, та можуть бути модифікованими.

Тютюнокуріння $є$ однією з головних проблем охорони здоров'я світу, зокрема Європи, і найчастішим фактором ризику розвитку IXC. Згідно з даними [23], близько 40 \% чоловіків-європейців залежні від тютюну, що є вищим показником, ніж у інших регіонах світу, а серед українських чоловіків цей показник становить ще більше - 49,5 \% [5]. Дана звичка зумовлює 650 тис. випадків смерті населення Європи щорічно [23], в Україні, відповідно, - 120 тис. [5]. За оцінками ВООЗ, близько 30 \% населення України курить. Причому, найвищий рівень куріння серед чоловіків виявлений у віковій групі 25-39 років, а серед жінок - 15-24 роки [25].

Внаслідок проведеної антитютюнової кампанії, площа посівів тютюну у всьому світі у період з 1995 року по 2012 рік знизилась на 10,6 \%, тоді як в Африці вона збільшилась на 65,3 \%. За цей час виробництво тютюнової продукції на глобальному рівні зросло лише на 2,27 \%, а на Африканському континенті понад 35,7 \%, де близько 86,3 \% припадає на його східну частину. На жаль, більшість урядів цього регіону не проводять активну політику у боротьбі з курінням, побоюючись негативних економічних наслідків. Поширеність цієї звички в світовому масштабі знизилась з $27 \%$ у 2000 році до $21 \%$ в 2012 році, тоді як в Африці навпаки, збільшилась з 13 до 15 \%. Це, у свою чергу, суттєво підвищує частоту виникнення IXC серед жителів даного материка [24].

У всьому світі частота виявлення АГ у дорослому віці дорівнює 22 \% [14]. В Європі поширеність цієї 
нозології дещо вища - 23 \% (рис. 2) [12]. За даними популяційних досліджень [4], більше 30 \% дорослого населення України страждає від підвищення артеріального тиску, причому в осіб похилого віку ця частка становить 40-45 \%. За оцінками експертів [14], у 2025 році у світі число осіб із підвищеним артеріальним тиском досягне 1,6 мільярда чоловік.

Поряд із високою поширеністю, АГ є також одним 3 основних чинників ризику захворюваності та смертності від IXC і зумовлює значні медичні й соціальні проблеми в Європі. Так, з 25 \% випадків інфаркту міокарда провідним чинником була власне АГ [27].

АГ $\epsilon$ найпотужнішим фактором ризику розвитку IXC і на Африканському континенті, уражаючи майже 30 \% населення (рис. 2) [12]. Кожен шостий житель Африки страждає від підвищення артеріального тиску. В Західній Африці поширеність АГ серед сільського населення у віковій категорії понад 65 років становить
30-40 \%, а серед міського ще більше - 50 \%. Ймовірно, приблизно у 40 \% пацієнтів АГ не діагностується. 3 тих пацієнтів, яким встановлено діагноз АГ, 30 \% не отримують медикаментозного лікування, і лише 20 \% хворих отримують адекватну антигіпертензивну терапію із досягненням цільових рівнів артеріального тиску $[22,21]$. До 2025 року кількість африканців з АГ досягне 150 мільйонів осіб [16].

Епідеміологічні дослідження [13] продемонстрували провідну роль ожиріння та надмірної маси тіла як найчастіших популяційних факторів ризику і прогресування IXC у США (рис. 3). Більше третини людей серед дорослого населення у всьому світі мають надмірну масу тіла, 13 \% страждають від ожиріння. Серед жителів США цей показник $є$ найвищим серед інших регіонів планети та досягає майже 34 \%. Розповсюдженість ожиріння в Європі складає в цілому близько 23 \%, а в Україні - $20 \%$.

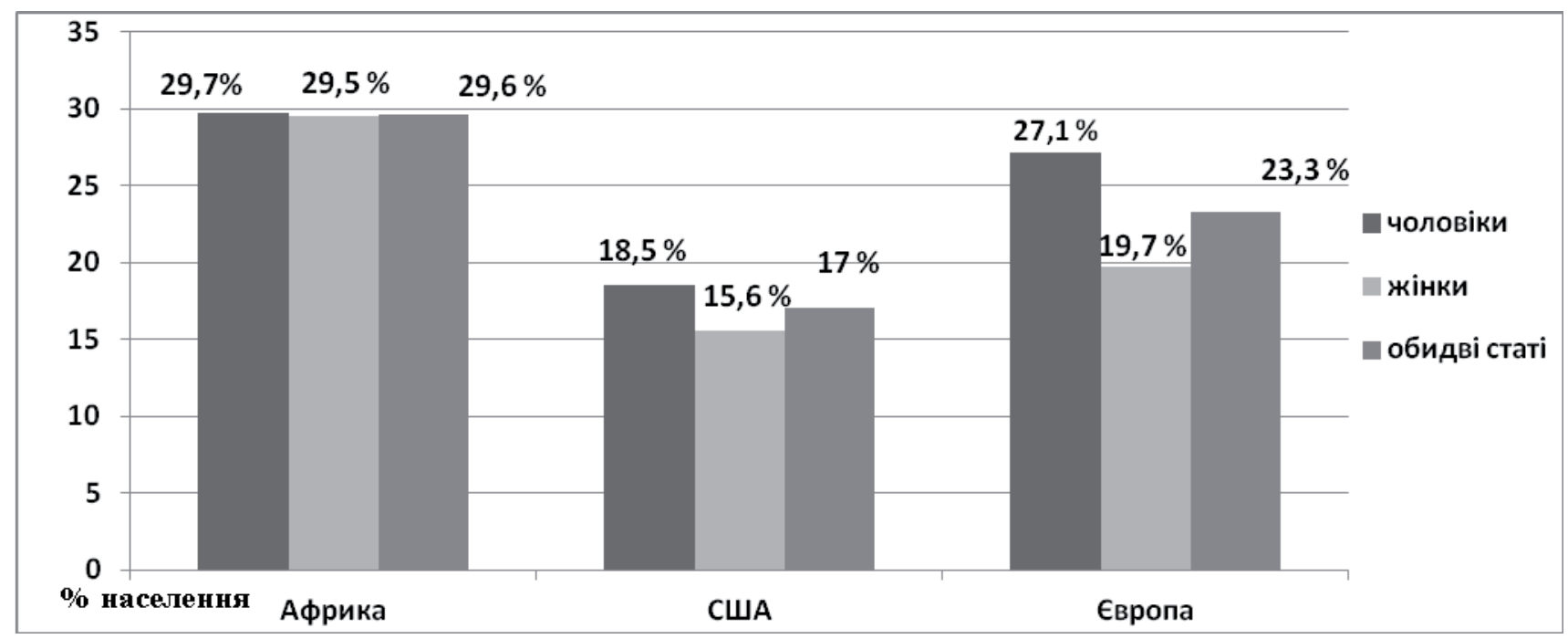

Puc. 2. Поширеність АГ у різних регіонах світу, 2014 рік [12].

Для ліпідограми більшості жителів Африки характерні нормальні показники рівня загального холестерину та підвищення ліпопротеїдів високої щільності, що вказує на невисоку значимість даного фактора ризику в розвитку IXC та зумовлює в цілому низьку поширеність ожиріння та дисліпідемії серед населення Африки [21].

Кількість хворих на ЦД досягла загрозливого масштабу епідемії і становить на сьогодні 387 мільйонів осіб, що складає 8,3 \% світової популяції. Фінансові витрати, пов'язані з цією проблемою, досягли 612 мільярдів доларів за 2014 рік. За даними шостого Атласу Діабету Міжнародної Діабетичної Федерації, найбільша поширеність ЦД зареєстрована у США -
11,39 \%, а предіабет встановлено у 86 мільйонів жителів. Щорічно у цій країні кількість хворих на ЦД збільшується на 1,7 мільйона. У Європі поширеність даного фактора ризику IXC є дещо нижчою - 7,9%, а в Україні лише 3,17 \% [16].

Приріст поширеності діабету в світі за 2003-2013 рр. в країнах Європи та України мав від'ємну тенденцію відповідно, -12,8 та - 69,2 \%, у той час, як у країнах Африки +137,5 \% [6]. Широке використання високоактивної ретровірусної терапії у боротьбі з ВІл/ СНІДом у країнах Африки призвело до підвищення показників поширеності цукрового діабету. За результатами International Diabetes Federation, близько 22 мільйони африканців хворіють на дану нозологію, 


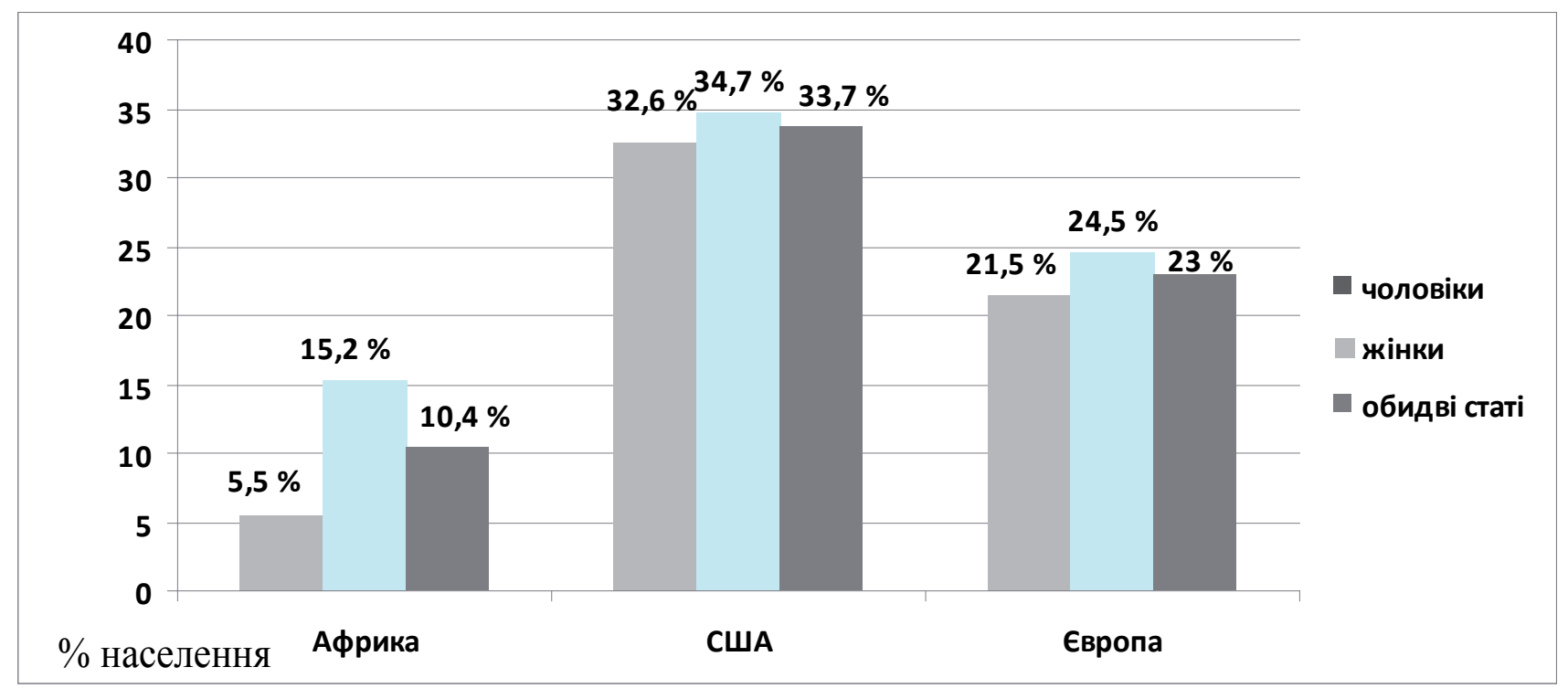

Puc. 3. Поширеність ожиріння у різних регіонах світу, 2014 рік [13].

у 62,5 \% осіб ще не діагностований [16]. Очікується, що до 2030 року масштаби поширення діабету зростуть до 28 мільйонів осіб [9].

Таким чином, незалежно від континенту чи країни проживання кожен житель планети гіпотетично може захворіти на IXC. Для профілактики даної патології насамперед потрібно впливати на модифіковані фактори ризику, такі як тютюнокуріння, гіподинамія, нераціональне харчування, ожиріння, дисліпідемія, ЦД, АГ. Причому поширеність того чи іншого фактора залежить від географічної позиції країни.

В Європі суттєвий вплив на поширення IXC серед населення здійснюють куріння, АГ та ожиріння, в той час, як у США головну роль відіграють ожиріння та ЦД. Для країн Субсахаральної Африки провідним фактором $\epsilon$ АГ, але поряд з цим зростає суспільне значення тютюнокуріння та швидкі темпи поширення ЦД.

Для кращої ефективності профілактики розвитку IXC потрібно адаптувати світовий досвід до реалій кожної країни. У Європі та Африці пріоритетом має стати проведення державної політики у боротьбі з курінням та підвищення інформованості населення про серйозні наслідки ускладнення АГ, поширення інформації про те, як запобігти розвитку цього захворювання. Для уряду США актуальним $\epsilon$ депопуляризація закладів швидкого харчування та газованих напоїв з високим вмістом цукру, пропаганда дієтичного харчування та збільшення щоденної фізичної активності. Цьому завданню може посприяти впровадження програмних додатків для смартфонів, які 6 допомагали стежити за калорійністю спожитої їжі та балансом макронутрієнтів, витратами енергії під час тренувань та змінами маси.

Висновок. Важливим у профілактиці IXC є відмова від куріння, дотримання дієтичного харчування, підвищення фізичної активності, контроль артеріального тиску, ліпідограми та рівня глікемії.

\section{ЛІТЕРАТУРА}

1. Європейська база даних статистичної інформації «Здоров'я для всіх» [Електронний ресурс].

2. Настанова з кардіології / за ред. В. М. Коваленка. - К. : Моріон, 2009. - 1348 с.

3. Пропозиції МОЗУкраїни щодо реформування галузі. К., 2010. - 103 c.

4. Радченко Г. Д. Перебіг артеріальної гіпертензії залежно від наявності супутньої ішемічної хвороби серця / Г. Д. Радченко, Л. О. Муштенко // Український кардіологічний журнал. - 2014. - № 2. - С. 18-28.

5. Смірнова І. П. Тютюнопаління та здоров'я жінок / І. П. Смірнова, О. О. Кваша // Нова медицина. - 2005. № 4 (21). - С. 14-17.

6. Ткаченко В. І. Аналіз поширеності та захворюваності на цукровий діабет серед населення світу та України за 2003-2013 рр. / В. І. Ткаченко // Ліки України. - 2014. Т. 21, № 4. - С. 55-59.

7. Уніфікований клінічний протокол медичної допомоги, гострий коронарний синдром з елевацією сегмента ST // МОЗ України. - 2013. - 8 с. 
8. Хвороби системи кровообігу як медико-соціальна і суспільно-політична проблема / за ред. Коваленка В. М., Корнацького В. М., - К. : 2014. - 280 с.

9. Addo J. Hypertension in sub-Saharan Africa: A systematic review / J. Addo, L. Smeeth, D. A. Leon Hypertension. - 2007. Vol. 50(6): P. 1012-1018.

10. European cardiovascular disease statistics / S. Allender, P. Scarborough, V. Peto [et al.] 2008 edition. British Heart Foundation Health Promotion Research Group, Department of Public Health, University of Oxford; Health Economics Research Centre, Department of Public Health, University of Oxford.

11. Focused update of the ACC/AHA 2004 Guidelines for the management of patients with ST elevation myocardial infarction / M. A. Elliott, M. Hand, P. W. Armstrong [et al.] // Circulation. - 2008. - Vol. 117. - P. 296-329.

12. Global Health Observatory (GHO) data, Blood Pressure, доступно на сайті http://www.who.int/gho/ncd/risk_factors/ blood_pressure_prevalence/en/.

13. Global Health Observatory (GHO) data, Overweight and obesity, доступно на сайті http://www.who.int/gho/ ncd/risk_factors/overweight/en/.

14. Global status report on no communicable diseases, World Health Organization. -2014. - Vol. 280. - P. 256-264.

15. Heart Disease and Stroke Statistics, American Heart Association. - 2015. Vol. 22. - P.10-15.

16. International Diabetes Federation. Diabetes Atlas, 6th edn, 2014.

17. Cardiovascular risk factors in sub-Saharan Africa: a review / M. Monti, M. P. Ruggieri, G. M. Vincentelli [et al.] // Italian Journal of Medicine 2015. - Vol. 9. - P. 305-313.

18. Murray C. J. Alternative projections of mortality and disability by cause 1990-2020: Global Burden of Disease
Study / C. J. Murray, A. D. Lopez // Lancet. - 1997; Vol. 349. P. - 1498-1504.

19. Revised Burden of Disease Estimates for the comparative risk factor assessment / R. Norman, D. Bradshaw, M. Schneider [et al.] South Africa 2000. Cape Town: Medical Research Council, 2006.

20. Ntsekhe M. Recent advances in the epidemiology, outcome, and prevention of myocardial infarction and stroke in subSaharan Africa / M. Ntsekhe, A. Damasceno // Heart. - 2013. Vol. 99. - P. 1230-1235.

21. Onen C. L. Epidemiology of ischaemic heart disease in sub-Saharan Africa / C. L. Onen // Journal of Africa. - 2013. Vol. 24. - № 2. - P. 34-42.

22. Opie L. H. Hypertension in sub-Saharan African populations / L. H. Opie, Y. K. Seedat Circulation 2005. Vol. 112(23). - P. 3562-3568.

23. Mortality from smoking in developed countries / R. Peto, A. D. Lopez, J. Boreham, M. Thun. - 1950-2000. 2nd ed. Oxford: Oxford University Press; 2003.

24. Status of Tobacco Production and Trade in Africa Factsheets / WHO Library Cataloguing-in-Publication on Data / World Health Organization 2015 and United Nations Conference on Trade and Development: 24.

25. WHO global report on trends in prevalence of tobacco smoking 2015, WHO Library Cataloguing-in-Publication Data. Vol. 359. - P. 337-338.

26. World health statistics. - 2015. - Vol. 161.

27. INTERHEART Study Investigators. Effect of potentially modifiable risk factors associated with myocardial infarction in 52 countries (the INTERHEART study): case-control study / Yusuf S., Hawken S., Ounpuu S. [et al.] // Lancet. - 2004. Vol. 364. - 937-952. 